\title{
Biochemical Changes of Dried Fruit of Figs (Ficus carica L.) During Storage
}

\author{
MIHAELA GABRIELA DUMITRU* \\ University of Craiova, Faculty of Science, Department of Chemistry, 107i Calea Bucuresti, 200585, Craiova, Romania
}

Fig (Ficus carica) is the fig tree, originating in the Mediterranean Basin, has a carnous and juicy pulp, besides being slightly sweetened. Fig is the highly perishable subtropical fruit, therefore, falls into high degradation due to biochemical changes that occur during storage. The purpose of this paper was to establish biochemical changes with a role in modifying the quality of fig fruit (Ficus carica) during the storage period. During storage, fruit containing oil is susceptible to oxidative damage. In order to ensure a high quality of fruit, it is essential to reliably analyze their oxidative status (complex process due to the influence of several factors such as availability of oxygen, light, temperature, microorganisms and enzymes). Samples were packed in $200 \mathrm{~mm} \times 150 \mathrm{~mm}$ polyethylene sheets and stored under ambient conditions to study the quality changes during storage for 365 days. The samples were analyzed for quality attributes, such as the measurement of fatty acid profiles, determination of primary oxidation products (Peroxide value), determination of secondary oxidation products (Thiobarbituric acid test), acid value and the refraction index. can help to estimate the shelf life. The result of the study indicated the shelf life for Ficus carica fruit dried was 120 days.

Keywords: Ficus carica, storage, lipids, oxidation stability

The common ûg (Ficus carica L.), a deciduous tree belonging to the Moraceae family, is one of the earliest cultivated fruit trees and an important crop world wide for both fresh and dry consumption [1]. Fruits they provide many nutrients that are essential for the health and maintenance of our bodies. They are commonly consumed fresh, but can also be eaten in a dried state. Almost all dried fruits provide essential nutrients and an array of health protective bioactive ingredients that help to reduce its risk of illness by preventing chronic diseases [2] also they have highest dietary index value of 11 as compared to other fruits [3]. Fig fruits being highly perishable cannotbe stored for longer period [4].

Drying is one of the most practical methods of preserving foods and fruits. Drying enhances the shelf life of products without loosing its nutritional qualities [5].

Maintaining nutritional qualities depends mainly on the storage conditions and the chemical composition of the fruit. Fruits with a significant lipid content are affected by the action of oxygen during storage becoming rancid.

Rancidity is a chemical reaction of fats and oils that produces off flavours and off odours. Fats and oils go rancid because of two chemical processes: hydrolytic rancidity and oxidative rancidity. Hydrolytic rancidity occurs when the fat (triglyceride) is broken up into free fatty acids and glycerol by the presence of water. The presence of the enzyme lipoprotein lipase (LPL) quickens this process. The unfavorable odour and flavour are the results of tasting individual short chain fatty acids instead of the whole triglyceride. Oxidative rancidity occurs in fats and oils that contain unsaturated fatty acids; mostly because unsaturated fats are less stable than saturated fats. Oxidation produces an accumulation of aldehydes and ketones, which are compounds that are also responsible for the unfavorable flavours and odours. Heat, light, oxygen, and metal ions encourage (speed up) oxidative rancidity [6].

The mechanism of oxidative rancidity has been extensively studied. Rancidity takes place through auto- oxidation because the rate of oxidation increases as the reaction proceeds. Oxidation takes place through a freeradical chain mechanism involving three stages [6; 7]

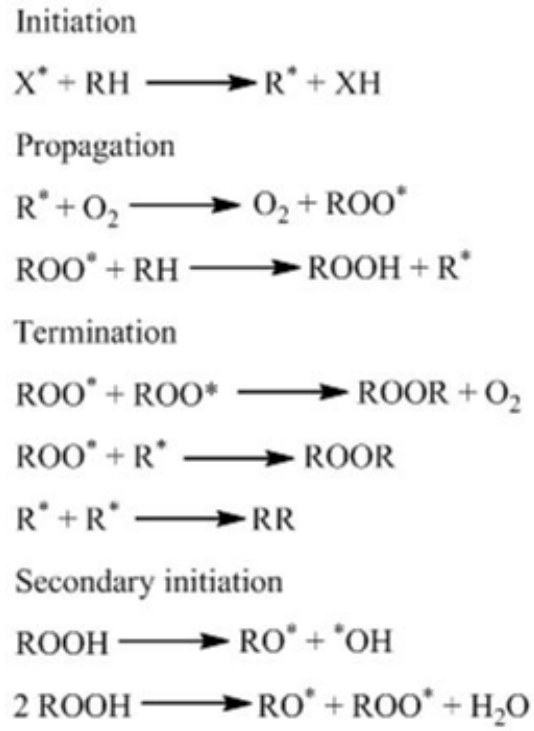

The hydroperoxides $(\mathrm{ROOH})$ formed in the propagation part of the reaction are the primary oxidation products. They are generally unstable and decompose into secondary oxidation products which include a variety of compounds. Among the secondary oxidation products, aldehydes and alcohols form an important group. The volatile aldehydes are mainly responsible for the oxidized or rancid flavour of fats [8].

The objective of this investigation was aimed to study the effect of storage time on lipid content of Ficus carica fruits. 


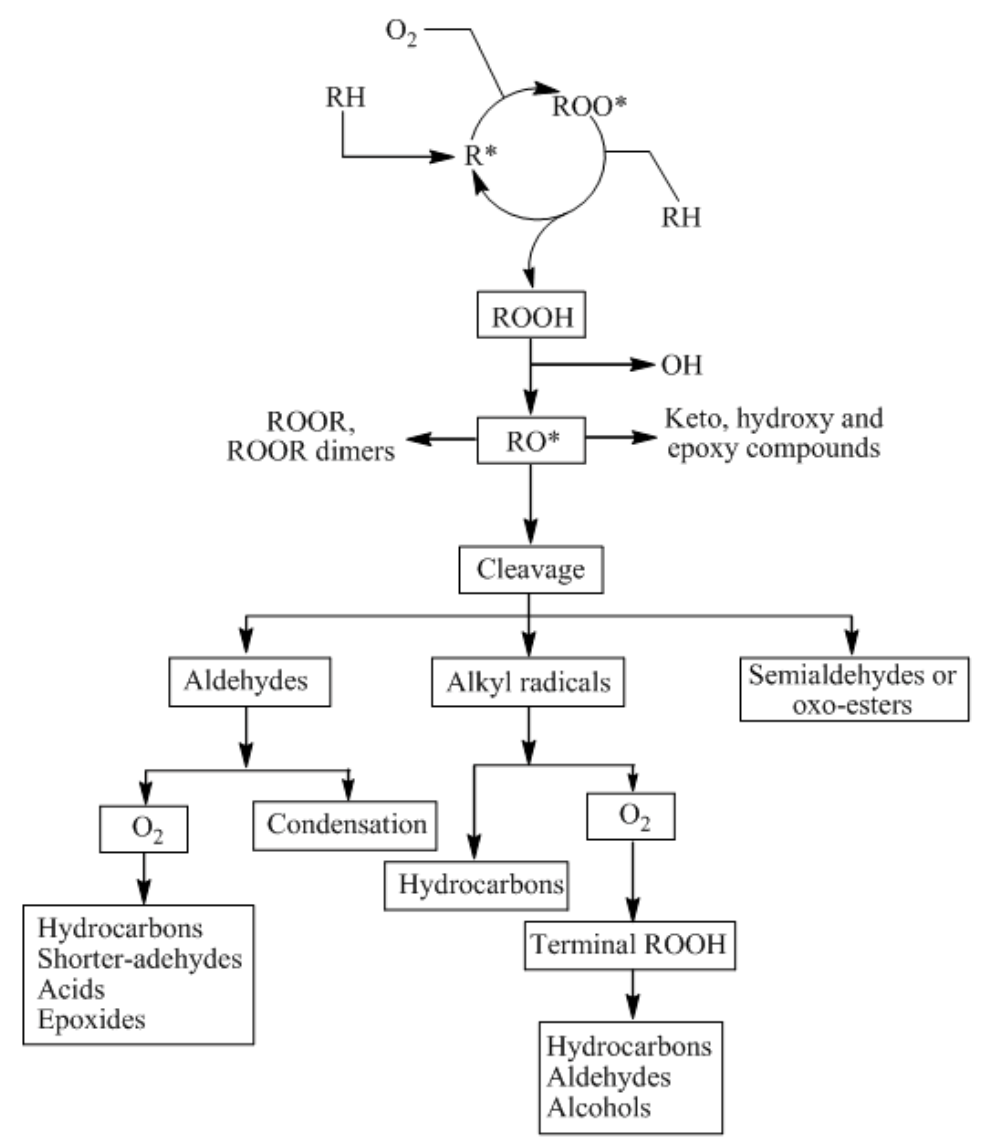

Fig. 1. Generalised scheme for autoxidation of lipids (From Aruna Palta)

\section{Experimental part}

Fruits of Ficus carica were washed thoroughly with tap water, blanched in hot water at $90^{\circ} \mathrm{C}$ for $5 \mathrm{~min}$ and then sulphurized with immersion in $0.2 \%\left(2 \mathrm{~g} \mathrm{~L}^{-1}\right)$ sodium metabisulfite solutions for 30 min and was dried in Vacuum oven VO - Memmert. Drying temperature was $60^{\circ} \mathrm{C}$. Drying lasted until is reached a moisture content of about $15 \%$.

Samples were packed in $200 \mathrm{~mm} \times 150 \mathrm{~mm}$ polyethylene sheets and stored under ambient conditions to study the quality changes during storage for 365 days.

\section{Extraction of oil from the fruits Ficus carica.}

The extraction of oil from the fruits Ficus carica was carried out in a Soxhlet-type device using light petroleum solvent. The extraction time was $6 \mathrm{~h}$. After oil extraction, the excess solvent was distilled off reduced vacuum using a rotary evaporator $[9 ; 10]$.

\section{Preparation of fatty acid methyl esters (FAMEs)}

Preparation of FAMEs was carried out according to the modified ISO method [11; 12].

0.1 - $0.2 \mathrm{~g}$ of oil was dissolved in $10 \mathrm{~mL} 0.2 \mathrm{~mol} \mathrm{~L}^{-1} \mathrm{H}_{2} \mathrm{SO}_{4}$ prepared in anhydrous methanol. Esterification was performed by refluxing for $30 \mathrm{~min}$ at $100^{\circ} \mathrm{C}$. After cooling at room temperature, $10 \mathrm{~mL}$ of petroleum ether $(40-60)$ was added followed by $10 \mathrm{~mL}$ of deionized water, mixed gently and allowed to settle until the upper petroleum ether layer becomes clear. The distinct upper layer of methyl esters in petroleum ether was separated and used for analysis chromatographic.

\section{Analysis of FAME products by GC}

The chromatographic analysis was performed with a chromatograph Hewlett-Packhard type 6890 equipped with the column HP INNOWAX (polyethylene) $30 \mathrm{~m} \times 0.25$ $\mathrm{mm} \times 0.17 \mu \mathrm{m}$.

Working Conditions:

Column temperature: $100^{\circ} \mathrm{C}(\min ) \stackrel{15^{\circ} \mathrm{C} \mathrm{min}}{-1}-160^{\circ} \mathrm{C} \stackrel{5^{\circ} \mathrm{C} \mathrm{min}-1}{\longrightarrow} 240^{\circ} \mathrm{C}$ (7 or $\left.17 \mathrm{~min}\right)$

Carrier gas flow: $\mathrm{H}_{2}=2 \mathrm{~mL} \mathrm{~min}^{-1}$; Splittess injector, $280^{\circ} \mathrm{C}$;

The flame ionization detector

Detector temperature: $280^{\circ} \mathrm{C}$; Air flow: $350 \mathrm{~mL} \mathrm{~min}^{-1}$;

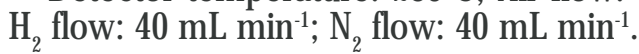

\section{Determination of primary oxidation products}

Peroxide value

The standard method prescribed by the AOAC 2015 [13] was performed to measure the peroxide value. In this procedure, the oil samples weighing $2 \mathrm{~g}$ were taken individually in different conical flasks and then a solution of acetic acid and chloroform in the ratio 3:2 is added. Later, the solution of saturated potassium iodide of $0.5 \mathrm{~mL}$ is mixed up with samples in every flask. All the flasks are then undisturbed for $5 \mathrm{~min}$. Now the distilled water measuring $15 \mathrm{~mL}$ is added to each flask and then titrated with a sodium thiosulfate solution of $0.1 \mathrm{~N}$ until the yellowish color disappears. Finally, $0.5 \mathrm{~mL}$ of starch is added and the titration is continued till the end point where the mixture turns colorless. The peroxide values was calculated according to the formula [14; 15]:

$$
\text { Peroxide values }=\frac{\left(V_{2}-V_{1}\right) \times T \times 1000}{m}
$$

where:

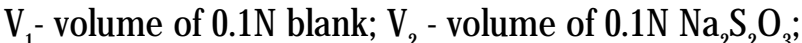
$\mathrm{T}^{1}$ - normality of $\mathrm{Na}_{2} \mathrm{~S}_{2} \mathrm{O}_{3} 0.1 \mathrm{~N} ; \mathrm{m}$ - mass of oil taken.

\section{Determination of secondary oxidation products} Thiobarbituric acid test

TBA value was tested by using the method of Buege and Aust [16] with slight modification. $0.5 \mathrm{~g}$ sample of fig was homogenated and mixed with $2.5 \mathrm{~mL}$ of $0.375 \%$ TBA 
solution, $15 \%$ tricloric acid (TCA) and $0.25 \mathrm{~N}$ of hydrochloric acid $(\mathrm{HCl})$. The mixture was heated for $10 \mathrm{~min}$ at boiling temperature $\left(100^{\circ} \mathrm{C}\right)$ to allow the formation of pink colour. Then, the solution was cooled and $1 \mathrm{~mL}$ of chloroform was added into the solution. The solution was centrifuged at $5500 \mathrm{rpm}$ for $25 \mathrm{~min}$. The absorption of supernatant was determined by using a spectrophotometer at wavelength of $532 \mathrm{~nm}$. TBA value was expres sed in miligrams of malonaldehyde (MA) equivalents per kilogram sample. The TBA value calculated based on the following formula [17]:

TBA value $=$ Reading at $532 \mathrm{~nm} \times 2.77$

\section{Acidity value}

Two gram of the oil was weighed accurately by transfer method into a $250 \mathrm{~mL}$ conical flask. Neutral ethanol (20 $\mathrm{mL}$ ) was added by means of a pipette and the flask heated on a steam bath for $3 \mathrm{~min}$. Then the flask was cooled and the contents titrated with $0.1 \mathrm{~N}$ alcoholic potassium hydroxide solution using phenolphthalein as an indicator. A blank titration was also conducted side by side [18].

\section{The refraction index}

The refraction index, Ir, is determined with a refractometer Abbe and is altered together with the growing of oxidation degree of the oil. A bigger degree of oxidation leads to the growing of refraction index. The results are expressed as ${ }^{\circ}$ Brix [19].

\section{Results and discussions}

Oxidation of unsaturated fatty acids is the main reaction responsible for the lipid degradation, which is related to the final quality of the product.

Lipid oxidation is a free radical chain reaction that leads to the development of unpleasant flavour and taste, loss of nutrients and formation of toxic compounds [20].
Consequently, the shelf life and the final use of any lipid depend on its resistance to oxidation or oxidative stability [20]. The term lipid oxidation usually refers to a three consecutive reactions or stages, known as initiation, propagation and termination.

Oxidative profile of edible oils is significant not only for forecasting the shelf-life of oils, but also for their long-term storage. The stability of edible oils generally depends on the composition of fatty acids. The effect of fatty acids on oxidative stability depended mainly on their degree of unsaturation and the position of the double bond within the molecule [21; 22].

Numerous analytical methods are routinely used for measuring lipid oxidation in foods. How ever, there is no uniform and standard method for detecting all oxidative changes in all food systems. Therefore, it is necessary to select a proper and adequate method for a particular application [23].

The available methods to monitor lipid oxidation in this article were:

Analysis of FAME products by GC, Determination of primary oxidation products (Peroxide value), Determination of secondary oxidation products (Thiobarbituric acid test), Acid Value and Refraction index.

The chromatographic analysis of the oil of the fruit of Ficus carica, (fig. 2), showed a concentration of the major fatty acids (unsaturated), (table 1).

From the chromatographic analysis of the oil extracted from Ficus carica fruit, the main FAME constituents are: stearic acid (C18:0), oleic acid (C18:1), linoleic acid (C18:2), linolenic acid (C18:3) and a arachidonic acid (C20:4).

During storage, the concentration of the main FAME constituents decreased by $9.5 \%$ for stearic acid, $14.2 \%$ for oleic acid, $27.9 \%$ for linoleic acid, 35.39\% for linolenic acid,

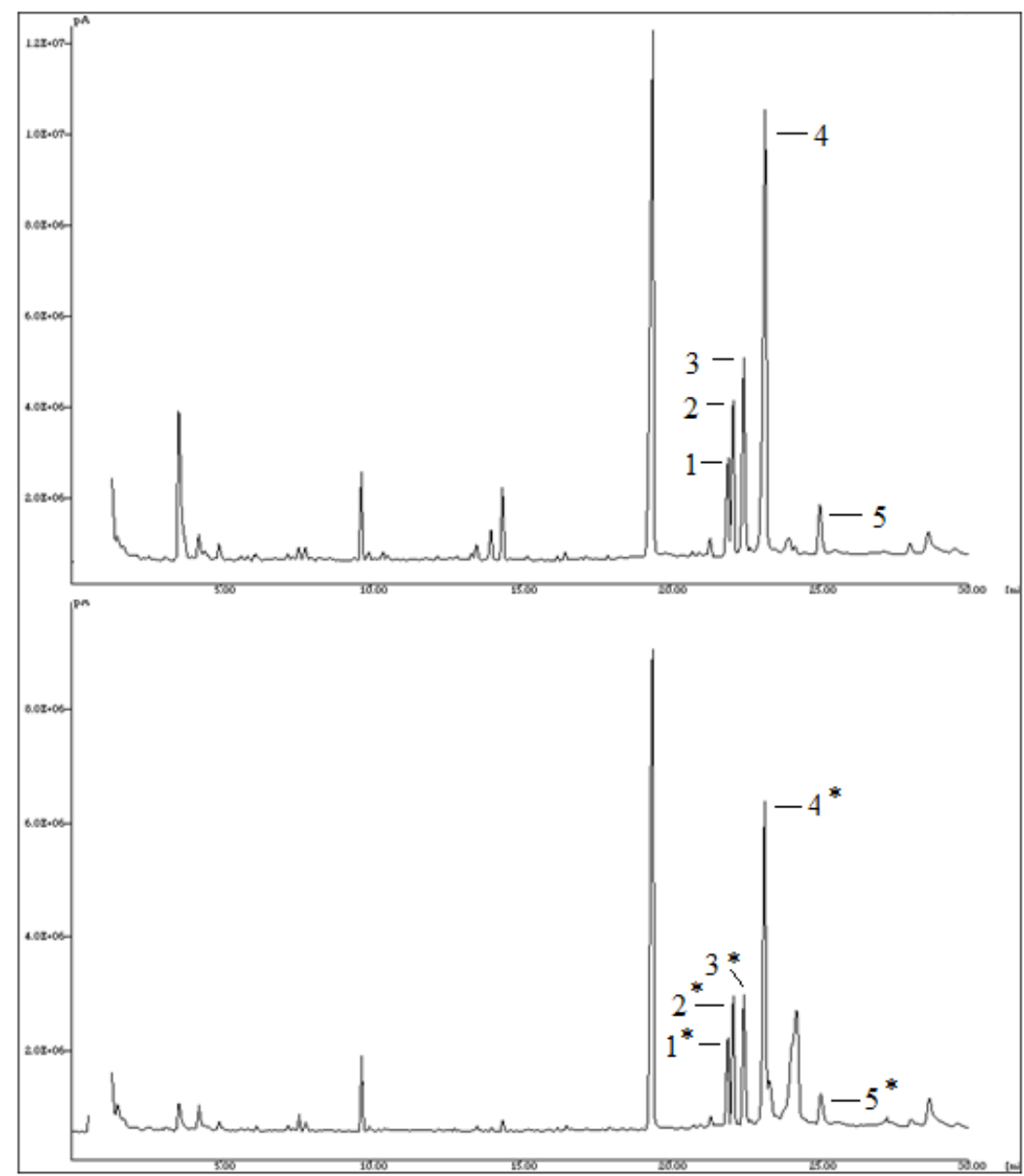

Fig. 2. The chromatographic analysis of FAME extracted from fruits of Ficus carica.

(1- stearic acid; 2- oleic acid; 3- linoleic acid; 4-linolenic acid; 5-arachidic acid) 
Table 1

FATTY ACIDS COMPOSITION OF FICUS CARICA FRUIT OIL

\begin{tabular}{|c|c|c|}
\hline $\begin{array}{l}\text { Name } \\
\text { compound }\end{array}$ & $\begin{array}{c}\text { Initial } \\
\text { Concentration, } \\
\mathrm{mg} 100 \mathrm{~g}^{-1}\end{array}$ & $\begin{array}{c}\text { Final } \\
\text { concentration, } \\
\mathrm{mg} 100 \mathrm{~g}^{-1}\end{array}$ \\
\hline Stearic acid & 4.2 & 3.6 \\
\hline Oleic acid & 16.9 & 14.5 \\
\hline Linoleic acid & 39.24 & 28.28 \\
\hline Linolenic acid & $96.1^{-1}$ & 62.09 \\
\hline Arachidonic acid & 1.95 & 1.11 \\
\hline
\end{tabular}

and $43 \%$ tor aracnıaıc acıa. Ine data obtaınea contırms that the stability of edible oils generally depends on the composition of fatty acids. The effect of fatty acids on oxidative stability depended mainly on their degree of unsaturation and the position of the double bond within the molecule [21].

As the number of double bonds in a fatty acid increases, its rate of oxidation increases. Thus, arachidonic acid is more prone to oxidation than linolenic acid followed by linoleic acid and oleic acid [24].

Table 2 presents the results of the determinations for samples of oil extracted from Ficus carica fruits.

\section{Determination of primary oxidation products}

Peroxide value

Oxidation, and the formation of peroxides, occurs during oil extraction and during storage. Peroxides are intermediate oxidation products of oil which lead to the formation of a complex mixture of volatile compounds such as aldehydes, ketones, hydrocarbons, alcohols and esters responsible for the deterioration of flavours [25].

The level of primary oxidation products, hydroperoxides, can be measured using peroxide value (PV) as a method. This is the oldest and most commonly used method for evaluating oxidative status in oils [26]. European Pharmacopoeia [27] has set the limit to PV $10 \mathrm{mEq} \mathrm{O}_{2}$ $\mathrm{Kg}^{-1}$ oil.

During the period of storage, the peroxide index of oil extracted from the Ficus carica recorded values placed on 2 storage periods.

First period are ranged from 0-120 storage days when IP values are between $3.3 \mathrm{mEq} \mathrm{O}_{2} \mathrm{Kg}^{-1}$ oil and $10.2 \mathrm{mEq} \mathrm{O}_{2}$ $\mathrm{Kg}^{-1}$ oil and second period of storage are between 120-365 days of storage when IP values are between $15.6 \mathrm{mEq} \mathrm{O}_{2}$ $\mathrm{Kg}^{-1}$ oil and $99 \mathrm{mEq} \mathrm{O}_{2} \mathrm{Kg}^{-1}$ oil.

According to the European Pharmacopoeia (2013) it is found that the storage period of Ficus carica fruits is 120 days, during which the IP reaches the admissible value of $10 \mathrm{mEq} \mathrm{O}_{2} \mathrm{Kg}^{-1}$ oil.

\section{Determination of secondary oxidation products \\ Thiobarbituric acid test}

The thiobarbituric acid (TBA) test is now one of the most extensively used methods to detect oxidative deterioration of fat-containing foods [23]. During lipid oxidation, malonaldehyde (MA), a minor component of fatty acids with 3 or more double bonds, is formed as a result of the degradation of polyunsaturated fatty acids. It is usually used as an indicator of the lipid oxidation process, both for the early appearance as oxidation occurs and for the sensitivity of the analytical method [28].

The basis of this test is the absorbance of a pink color complex at 532-535 nm which is formed between thiobarbituric acid (TBA) and oxidation products of polyunsaturated lipids.<smiles>CCCCC(=O)CC(=O)Nc1nc(=S)[nH]c(OC(C)C)c1CC=Cc1c(O)[nH]c(=S)[nH]c1=O</smiles>

Reaction of 2-thiobarbituric acid (TBA) and malonaldehyde (MA)

Table 2

RESULTS OF THE DETERMINATIONS FOR SAMPLES OF OIL EXTRACTED FROM FICUS CARICA FRUITS

\begin{tabular}{|c|c|c|c|c|}
\hline $\begin{array}{l}\text { Time, } \\
\text { months }\end{array}$ & $\begin{array}{l}\text { Peroxide value, } \mathrm{mEq} \\
\mathrm{O}_{2} \mathrm{Kg}^{-1} \text { oil }\end{array}$ & $\begin{array}{l}\text { Thiobarbituric acid, mg } \\
\mathrm{Kg}^{-1} \text { oil }\end{array}$ & $\begin{array}{l}\text { Acid Value, } \\
\mathrm{mg} \mathrm{KOH} \mathrm{g-1} \text { oil }\end{array}$ & $\begin{array}{l}\text { Refraction index } \\
\text { 'Brix }\end{array}$ \\
\hline 0 & 3.3 & 1.9 & 0.11 & 1.4661 \\
\hline 1 & 5.4 & 2.2 & 0.15 & 1.4662 \\
\hline 2 & $6.4^{-}$ & 5.7 & 0.25 & 1.4667 \\
\hline 3 & 8.5 & 10.8 & 0.34 & 1.4675 \\
\hline 4 & 10.2 & 16.7 & 0.42 & 1.4683 \\
\hline-5 & 15.6 & 22.0 & 0.65 & 1.4685 \\
\hline 6 & 21.8 & 31.0 & 0.79 & 1.4689 \\
\hline 7 & 32.4 & 42.0 & 0.83 & 1.4695 \\
\hline 8 & 45.6 & 55.2 & 1.00 & 1.4699 \\
\hline 9 & 53.2 & 74.0 & 1.40 & 1.4711 \\
\hline 10 & 62.7 & 79.8 & 1.56 & 1.4718 \\
\hline 11 & 71.8 & 82.0 & 1.89 & 1.4729 \\
\hline 12 & $99.0^{-}$ & 87.0 & 1.96 & 1.4735 \\
\hline
\end{tabular}


The extent of oxidation is reported as the TBA value and is expressed as milligrams of MA equivalents per kilogram sample or as micromoles of MA equivalents per gram of sample. The thiobarbituric acid (TBA) test determined to oil extracted from Ficus carica fruits presented an increase of MDA values which ranged between $1.9 \mathrm{mg} \mathrm{Kg}^{-1}$ oil and $87 \mathrm{mg} \mathrm{Kg}^{-1}$ oil. The variation in TBA values observed for oil of fruit can be an indication that there is indeed variation in the lipid contents which determine their variability in keeping quality with time.

\section{Acidity value}

The acidity value (AV) is a common parameter in the specification of fats and oils. It is defined as the weight of $\mathrm{KOH}$ in mg needed to neutralize the organic acids present in $1 \mathrm{~g}$ of fat and it is a measure of the free fatty acids (FFA) present in the fat or oil. An increment in the amount of FFA in a sample of oil or fat indicates hydrolysis of triglycerides. Such reaction occurs by the action of lipase enzyme and it is and indicator of inadequate processing and storage conditions (i.e., high temperature and relative humidity, tissue damage). The source of the enzyme can be the tissue from which the oil or fat was extracted or it can be a contaminant from other cells [29]. The acidity values of the oil samples extracted from Ficus carica fruits presented a low increase in the first 150 days of storage and are included 0.1 and $0.65 \mathrm{mg} \mathrm{KOH} \mathrm{g}^{-1}$ oil, and moderate increase on 150 days and 210 days with acidity ranges between $0.65 \mathrm{mg} \mathrm{KOH} \mathrm{g}^{-1}$ oil and $0.83 \mathrm{mg} \mathrm{KOH} \mathrm{g}^{-1}$ oil and pronounced increase during 210days-365 days with values of acidity ranged between $0.83 \mathrm{mg} \mathrm{KOH} \mathrm{g}^{-1}$ oil and 1.96 $\mathrm{mg} \mathrm{KOH} \mathrm{g}^{-1}$ oil.

\section{The refraction index}

The refraction index is an important index for quality. The variation in refraction index of oil extracted from Ficus carica fruits is the result of the accumulation of decompositions compounds that occur in the process of oxidation of lipids during storage [30]. The value of refraction index are between 1.4461p Brix at beginning of storage and $1.4735^{\circ}$ Brix after 365 storage days.

To observe the interaction between some parameters determined on the oil extracted from Ficus carica fruits, the correlations between the values of the Peroxide Index and the Acid Value, Thiobarbituric acid and Refraction Index were analysed.

Analyzing the determinant coefficient $R^{2}$ with values ranging from 0.9291 to 0.99502 indicates the intensity of the large variables, the link between them being strong.

The correlation coefficientr with values between 0.9639 and 0.9747 indicates a strong link between the parameters, figure 3-5.

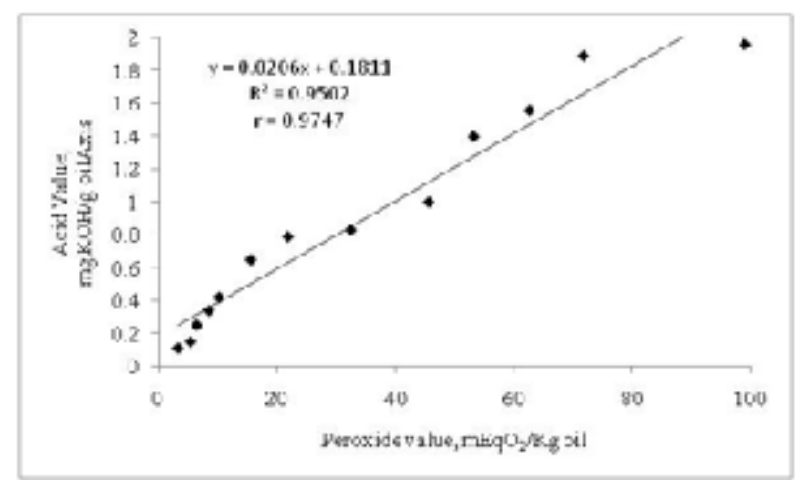

Fig. 3. Correlation between peroxide value and acid value

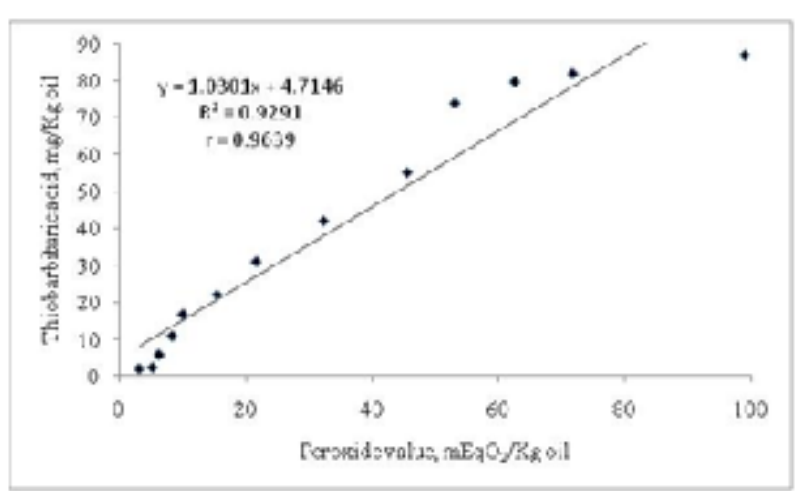

Fig. 4. Correlation between peroxide value and Thiobarbituric acid test

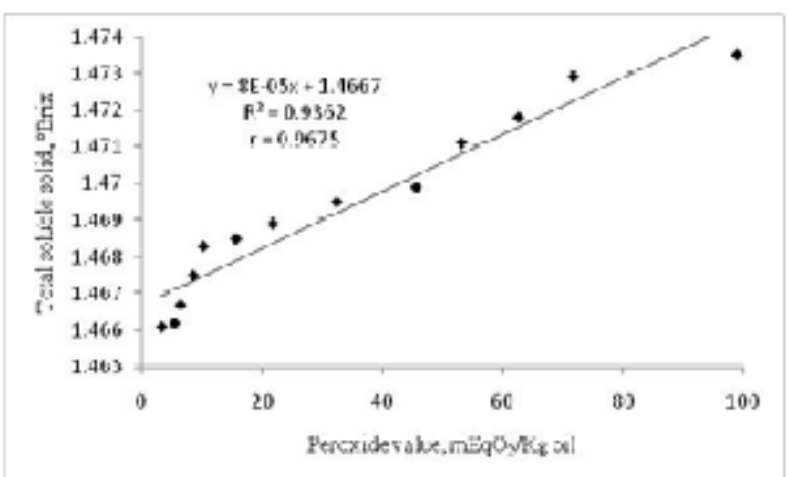

Fig. 5. Correlation between peroxide value and the refraction index

\section{Conclusions}

Among the compounds of organic nature, lipids are most prone to oxidation. Lipid oxidation is a severe problem for food industry. It is one of the major causes leading to generating reactive oxygen species (ROS) which are linked with several food deterioration. Food quality is deteriorated by the process of oxidation during storage. Reactive oxygen species, generated during this process, react with nutrients in food producing stable oxidation products which are dangerous to health. Due to these oxidative products nutritional quality and organoleptic value of foods is decreased making the food unacceptable to consumers. Under ambient conditions, fruit of Ficus carica cannot be stored for more than 120 days because of significant losses in some quality attributes.

Utilisation of the antioxidants during storage is very important to avoid quality damage, guarantee the consumer acceptance and retain the commercial value of the product.

\section{References}

1. SOLOMON, A., GOLUBOWICZ, S., YABLOWICZ, Z., GROSSMAN, S., BERGMAN, M., GOTTLIEB, H.E., ALTMAN, A., KEREM, Z., FLAISHMAN, M.A. J. Agric.Food Chem., 54, 2006, p. 7717.

2. SONI, N., MEHTA, S., SATPATHY, G., GUPTA, K. R., J. Pharmacogn. Phytochem., 3(2), 2014, p. 158.

3. DHUMAL, C. Y., DHEMRE, J. K., KAD, V. P., SHETE, M. B., J. Chem. Stud., 6(2), 2018, 183.

4. VEBERIC, R., COLARIC, M., STAMPAR, F., Food Chem., 106, 2008, p. 153.

5. NAGARAJA, K., SUNIL, C. K., CHIDANAND, D. V., RAMACHANDRA, M.,

I.J.S.A.R.T., 2(1), 2016, p. 126.

6. NUMMER, B., C WASHBURN, C., HUNSAKER, T., A guide to Food storage for emergencies, Ed. USU Extension, Utah State University, 2013, p. 37.

7. DUMITRU, M. G., GRECU, D. R., Bulg. J. Agric. Sci., 16(2), 2010, p. 227. 
8. PALTA, A., http://epgp.inflibnet.ac.in/epgpdata/uploads/ epgp_content/ 9. *** SR 13258/96

10. BITA, M.G., PREDA, M., Rev. Chim.(Bucharest), 56, no. 7, 2005, p.716.

11.*** BS EN ISO 5508 (1995).

12. KOSTIK, V., MEMETI, S., BAUER, B., J.H.E.D., 4, 2013, p. 112.

13. *** Official Methods of Analysis, 1980, p. 366.

14. MADHAVI, N., DEVA, SAROJA, T., Int. J. Pharm. Bio. Sci., 5(3), 2014,p. 437.

15. DUMITRU, M. G., TUTUNEA, D., Rev.Chim. (Bucharest), 68, no. 11, 2017, p. 2676.

16. BUEGE, J. A., AUST, S. D., Methods Enzymol., 52, 1978, p. 302.

17. KAMARUZAMAN, N., BABJI, A. S., AIP Conf. Proc., 1614(1), 2014, p. 317.

18. DUMITRU, M. G., Rev.Chim. (Bucharest), 67, no. 6, 2016, p. 1127.

19. DUMITRU (BITA), M. G., GRECU, D. R., TUTUNEA, D., POPESCU, A., BICA, M., REV. CHIM. (Bucharest), 61, no. 9, 2010, p. 882.

20. SALDANA, M.D.A., MARTÍNEZ-MONTEAGUDO, S. I., http://dx.doi.org

21. KAMAL-ELDIN, A. Eur. J. Lipid Sci. Technol., 108, 2006, p. 1051.
22. CAO, J., LI, H., XIN, X., ZOU, X. G., LI, J., ZHU, X. M., DENG, Z. Y., Int. J. Food Prop., 18, 2015, p. 808.

23. SHAHIDI, F., ZHONG, Y., https://doi.org

24. SHAHIDI,f., WEENEN, H., Food lipids. Chemistry. Flavour and Texture ACS Symposium Series; American Chemical Society: Washington, DC, 2005, p.145.

25. PRISTOURI, G., BADEKA, A., KONTOMINAS, M. G., Food Control, 21(4), 2010, p. 412-418.

26. FRANKEL, E. N., Lipid Oxidation, Edition 2, Ed. Woodhead Cambridge, UK, 2005, p. 470.

27. EUROPEANPHARMACOPEIA, Supplement 4.8., 2003, p. 4715.

28. ALAMED, J., https://scholarworks.umass.edu

29. MOORE, V. J., SHORB, J., PRAT-RESINA, X., WENDORFF, T., HAHN, A., https://chem.libretexts.org

30. BITA, M. G., PREDA, M., Procese redox la prãjirea i depozitarea cafelei, Ed. Universitaria Craiova, 2008. p.104.

$\overline{\text { Manuscript received: } 27.07 .2018}$ 